\title{
Different Matching in Public Goods Experiments with Punishment Opportunity
}

\author{
Zuzana Berná ${ }^{1}$ \\ ${ }^{1}$ Ekonomicko-Správní Fakulta, Masarykovy Univerzity, Katedra Veřejné Ekonomie, Brno - Pisárky, Czech \\ Republic \\ Correspondence: Zuzana Berná, Ekonomicko-Správní Fakulta, Masarykovy Univerzity, Katedra Veřejné \\ Ekonomie, Brno - Pisárky, Czech Republic, Lipová 41a, Brno - Pisárky 60200, Czech Republic. Tel: \\ 420-549-493-234. E-mail: zuzana.berna@econ.muni.cz
}

Received: May 13, 2013 Accepted: June 10, 2013 Online Published: July 19, 2013

doi:10.5539/res.v5n4p30 URL: http://dx.doi.org/10.5539/res.v5n4p30

\begin{abstract}
This paper presents results of an experiment with Czech (and Slovak) University students replicating study of Denant-Boèmont, Masclet and Noussair (2007). The experiment focuses on impacts of different punishment opportunities in public goods game. The original experiment was executed in the so-called partner matching (where subjects interacted with the same co-players during the whole session). The author's aim was to enrich and complete the data with results obtained in stranger matching (where composition of groups changed randomly before each round of a session). The author argues that such extension is of relevance because real human interactions are often the strangers ones, that is, people are obliged to interact with unknown counterparts.

The results show that, in the case of stranger interactions, subjects are considerably less willing to cooperate and to engage in punishment of free riders. On the other hand, we can observe the same reactions in response to diverse opportunities to sanction. Both in cases of partners and strangers, the possibility to avenge sanctions reduces the willingness to cooperate while opportunity of sanction enforcement has an inverse effect. This finding endorses the conclusions of original experiment.
\end{abstract}

Keywords: cooperation, voluntary contribution mechanism, decentralized punishment, partner matching, stranger matching

\section{Introduction}

One of the main tasks of experimental research in economics has been an attempt to explain the emergence of cooperation in situations of social dilemma (a term first employed by Dawes, 1975, 1980). Identification of individual incentives to cooperate in situations where economic rationality should lead agents not to, as well as factors having the capacity to influence the level of cooperation have been subject of laboratory testing in the last three decades.

A typical example of a social dilemma situation is voluntary contribution to public goods. In order to identify factors influencing level of contributions, experimenters have employed different schemes and modifications of classic Voluntary Contribution Mechanism (hereafter "VCM"). One such modification is VCM with opportunity to punish free riders. The mechanism is as follows: After all individual decisions are made, information about individual levels of contribution to a public good is published and individuals get opportunity to sanction their co-players. As this means sanctioning without intervention of external authority, we speak about so-called decentralized punishment (Nikiforakis, 2007). Received sanction reduces current income of punished subject and, at the same time, the act of punishment brings cost also to the sanctioning subject. As it doesn't ensure any future financial benefit to the latter, we can speak also about so-called altruistic punishment (Fehr \& Gächter, 2002). Other appellations such as costly or peer punishment (see e.g., Guala, 2012; Casari, 2012) are used to represent the same mechanism of decentralized punishment.

The very first experiments (Ostrom, Walker, \& Gardner, 1992; Fehr \& Gächter, 2000) demonstrated strong positive effect of opportunity of decentralized punishment on cooperation. In Fehr and Gächter's (2000) experiment, a possibility to punish free riders led to considerable increase in individual contributions. The authors concluded that, under the possibility of the decentralized punishment of free riders, a very high (or even full) 
cooperation may be achieved and maintained, while without this possibility the same subjects resume the act of full free riding.

Following studies (e.g., Nikiforakis, 2007; Denant-Boèmont et al., 2007; Nikiforakis \& Engelmann, 2011) have shown, however, that efficacy of this mechanism has several limitations. For instance, the positive effect of punishment is maximized when players get unique opportunity to impose sanctions on free-riders while the latter don't know who sanctioned them. Yet, such (artificial) limitation doesn't enable subjects to engage in various punishment strategies like retaliation (that is, sanctioning of those who assigned us a punishment; what we call counterpunishment), sanction enforcement and so forth. Experiments enabling multiple punishment opportunities, counter-punishment or feuds show that former positive effect of punishments is often outweighed by these strategic considerations. Furthermore, decentralized punishment is effective only under a specific cost-impact ratio (see Nikiforakis \& Normann, 2008; or Egas \& Riedl, 2004). Experimental results have shown that in deciding whether to engage in altruistic punishment or not, the subjects take into account costs and effects of their actions. And finally, decentralized punishment is more effective if combined with other cooperation-enhancing mechanisms. It has been shown for instance (see Ostrom et al. 1992; or Bochet, Page, \& Putterman, 2006), that decentralized punishment is more effective if combined with possibility of (verbal) communication.

This paper presents results of experiment replicating study of Denant-Boèmont et al. (2007). The authors studied impacts of possibility of so-called counter punishment (the term first used in Nikiforakis, 2007) and sanction enforcement at the level of contributions. In this experiment, players had opportunity to retaliate imposed sanctions (counter punishment) and/or engage in repeated sanctioning of low contributors in order to enhance cooperation (sanction enforcement). Sanction enforcement may take two forms: sanctioning of those who fail to punish low contributors and those who punish high contributors. The authors raised a question on whether the effect of sanctioning enforcement on cooperation would be stronger than the effect of counter-punishment or vice versa. According to the results, significant negative effect of counter-punishment prevailed over the positive one of sanction enforcement (which was not statistically significant) and the overall effect was negative. The second issue the authors examined was the effect of multiple opportunities to sanction. (Note 1)

The original experiment was executed in so-called partner matching (where subjects interacted with the same co-players during the whole session). The author enriches the research with data obtained under stranger matching (where composition of groups changes randomly before each round of a session). The results show that, in case of stranger interactions, subjects are considerably less willing to cooperate and engage in punishment of free riders. As in case of original experiment, the possibility to avenge sanctions reduces the willingness to cooperate while the opportunity of sanction enforcement has an inverse, that is, positive effect.

In order to eliminate so-called country effects, the author executed another set of experiments using partner matching. The results obtained were ambiguous; while the data confirmed author's hypothesis concerning higher level of cooperation in partner matching; it demonstrated lower willingness of subjects to sanction free riders. As the level of average contribution was very high in all partner groups, the absence of punishment in this case may be interpreted as effectiveness of this tool in enhancing cooperation.

\subsection{Motivation}

The aim of experiment presented in this paper was to enrich and complete the data acquired by Denant-Boèmont et al. (2007) by results obtained via stranger matching. The motivation was the question whether a different matching type would influence individual contributions and willingness to engage in costly punishment or not. The author considers this extension to be of relevance because in reality, people often meet and are obliged to interact with counterparts they haven't interacted with before and/or won't interact with in a future. Or, as Fehr and Gächter (2002) state: "[...] people frequently cooperate with genetically unrelated strangers, often in large groups, with people they will never meet again, and when reputation gains are small or absent" (p. 137).

The original experiment (Denant-Boèmont et al., 2007) was executed in partner matching which means that subjects interacted with the same co-players in every round of an experimental session. Alternative setting, the so-called stranger matching, implies that group composition changes randomly before each round, and such setting represents a good approximation to single-shot experiments since reputation effects are eliminated (a "perfect approximation" would be under perfect stranger matching ensuring that two subjects don't meet more than once during a session).

If reputation matters one would expect partners to cooperate significantly more than strangers (Andreoni \& Croson, 2008). However, the first study dealing with this question (Andreoni, 1988) showed just the opposite. Starting with the former paper, there has been an intensive discussion whether cooperation is higher under partner setting or not. Andreoni and Croson (2008) bring a synthesis of replications and studies on this topic. According to it, the picture 
remains quite unclear, as "four studies find more cooperation among strangers, five find more by partners and four fail to find any difference at all" (p. 777).

In order to eliminate country effects from the analysis, the author conducted a separate control session in which subjects acted as partners. By doing so, she wanted to rule out the possibility that differences in contributions would be caused partly by different cultural background of experimental subjects (for example by general (dis)inclination of the Czechs to contribute to public goods). The study of Herrmann, Thöni, and Gächter (2008) showed that there might be a huge variation in contribution and punishment behavior across different societies. Nemec (1998) emphasized the economic and social specifics of transitive economics countries relative to individual behavior. The previous Czech results (see Šeneklová \& Špalek, 2009; or Špalek \& Berná, 2011, 2012), however, demonstrated no important disparities between the Czech and foreign results related to the voluntary contribution mechanism.

\section{Method}

\subsection{Overview}

The experiment consisted of four different treatments which were replication of Denant-Boèmont et al. (2007). Set of stranger experiments took place at Masaryk University in Brno during academic year 2009-2010. The participants were recruited among undergraduate students of different faculties of Masaryk University by means of an advertisement published in University's information system. Each treatment constituted a single session in which 24 subjects took part. In total, 96 subjects participated in the experiment. Average individual earning was $230.5 \mathrm{CZK}$. All experimental sessions were executed on computer terminals using z-Tree program (Fishbacher, 2007).

To check possible country effects, the author also conducted four partner sessions (one for each treatment). 24 subjects participated in each of them except for Revenge Only treatment (see below for explanation) in which only 20 players took part (92 participants in total). The partner sessions took place at Masaryk University during academic year 2012-2013. Average earning of partners was 281.5 CZK.

Each of the four treatments consisted of 20 identical rounds (repetitions). Subjects acted in groups of four players. The composition of a group was anonymous and either fixed (partner matching) or changing randomly within each round (stranger). At the beginning of each treatment, the participants played one trial round so that they make sure they understood the instructions.

The basic treatment called Baseline consisted of only two stages in each round. The first stage, which we may call the investment stage, was of a classical VCM. Within this stage, the participants were given a certain amount of disposable income and they had to decide which part of it they would keep on their personal account and which part they would invest in a group account. Then a punishment stage followed at the beginning of which the players learned about individual investments in the group account and they received a subsequent opportunity to assign points to their co-players, reducing their current income. At the end of the punishment stage, the players were informed about their original income (after the first stage), number of points received and of the total payoff from a round. The generators of imposed sanctions were hidden from the players.

The three other treatments contained one more punishment stage and the difference among them was the character of the published information about punishments assigned. In this third stage, the players had the opportunity to punish again all their co-players in a group. In the Revenge Only treatment, all players learned who specifically sanctioned them and by which amount. In the No Revenge treatment, on the other hand, they were informed about all the punishments excepting those assigned to them. Then, in the Full Information treatment, they learned about all the assigned punishments and their generators.

Different treatments allowed for use of various punishment strategies. In Baseline, the subjects used punishments only in response to contribution decisions made at the first stage. Revenge Only treatment allowed, in addition to above-mentioned, the use of counter-punishment. In No Revenge the possibility of counter-punishment was eliminated while the subjects were allowed to engage in sanction enforcement, as well as punishing their co-players in response to first-stage contributions. Full Information treatment allowed all the sanction strategies mentioned above. Therefore, the difference in the contribution levels between Baseline and Revenge Only treatments, as well as difference between No Revenge and Full Information, measures the marginal effect of counter-punishments on cooperation. On the other hand, the difference in contributions between Baseline and No Revenge, as well as between Revenge Only and Full Information, represents the marginal effect of sanction enforcement (Denant-Boèmont et al., 2007). 


\subsection{Calculation of Payoffs}

During the experiment, the payoffs were calculated in experimental monetary units - tokens. At the end of each session, the total sum acquired was converted into CZK, using the exchange rate of 1 token $=0.50 \mathrm{CZK}$, and subsequently paid to participants. The calculation of profits was based on Fehr and Gächter's (2000) design.

In the beginning of each of the investment stages, the subjects were given 20 tokens and were asked to decide how many tokens they would keep (on their personal account) or invest to a group account, which was common to all players in a given group. Each token kept on private account maintained its value (ratio 1:1), while each token invested to the group account yielded 0.4 tokens to every player of a group. Calculation of payoffs at the end of each investment stage is given by equation (1).

$$
\pi_{i}^{1}=20-g_{i}+0.4 \sum_{j=1}^{n} g_{j}
$$

$\pi_{i}^{1}$ represents the payoff of individual $i$ in given round, the integer 20 is her initial endowment (in tokens); $g_{i}$ is $i$ 's contribution to the group account (an integer from the interval [0 .. 20]), and the value 0.4 is the marginal payoff of the group account.

At the end of this investment stage, the subjects learned about their current profits and individual contributions (of their co-players) to the group account. Then a punishment stage followed whereas each player had the opportunity to reduce payoffs of their co-players by assigning them points ( $0-10$ points to each co-player). Each point received reduced its owner's profit by $10 \%$ while 10 and more points received meant reduction by $100 \%$ (not more). Assignment of points caused an increase of costs also to the punishing subject; he or she bore the cost from punishing each of co-players and these costs (for each co-player) were added up. The costs brought by punishing subjects were a convex function, punishment points and their amount is given by Table 1 .

Table 1. Cost function of points assigned

\begin{tabular}{llllllllllll}
\hline Points assigned & 0 & 1 & 2 & 3 & 4 & 5 & 6 & 7 & 8 & 9 & 10 \\
\hline Costs of points assigned by player & 0 & 1 & 2 & 4 & 6 & 9 & 12 & 16 & 20 & 25 & 30 \\
\hline Source: Fehr and Gächter (2000) & & & & & & & & & &
\end{tabular}

The calculation of individual payoffs at the end of the first punishment stage was given by equation 2 .

$$
\pi_{i}^{2}=\pi_{i}^{1}\left[\max \left\{0,1-(1 / 10) \sum_{j \neq i} p_{j i}\right\}\right]-\sum_{j \neq i} c\left(p_{i j}\right)
$$

where $c\left(p_{i j}\right)$ is convex cost function defined in Table 1 , assigning cost to player $i$ for punishing player $j$.

This payoff represented the total of the payoff within the Baseline treatment. In three other treatments one more punishment stage followed. Each point received reduced the current profit of its receiver by $10 \%$. The costs of punishments assigned were (again) calculated on the basis of Table 1. Total profit at the end of the second punishable stage (that is, total profit per round for the four treatments) was given by equation 3 .

$$
\pi_{i}^{3}=\pi_{i}^{1}\left[\max \left\{0,1-(1 / 10)\left[\sum_{j \neq i} p_{j i}^{2}+\sum_{j \neq i} p_{j i}^{3}\right]\right\}\right]-\sum_{j \neq i} c\left(p_{i j}^{2}\right)-\sum_{j \neq i} c\left(p_{i j}^{3}\right)
$$

where $p_{j i}^{2}$ is the punishment of player $i$ assigned by player $j$ in the second stage and $p_{j i}^{3}$ is also the punishment of player $i$ assigned by player $j$ in the third stage.

\subsection{Theoretic Assumptions}

In classic VCM, the game theoretic presumption is that no one would contribute to a public good (as dominant strategy of each player is to contribute nothing). An opportunity of decentralized sanction may be considered a second-order public good (see e.g., Fehr \& Gächter, 2002; or Guala, 2012) because while a (costly) sanction is imposed on the punisher, the whole group of contributors benefit from this act. As punishment means a financial penalty for the punisher, dominant strategy of players is again not to engage in this second order-public good, that is, not to impose sanctions. All individuals are aware of this and as the threat of punishment is not credible, they will contribute zero to a public good and the game will end in the same equilibrium outcome as the classic VCM. In this logic the number of punishment stages doesn't matter; the equilibrium situation will always correspond to zero contributions.

\subsection{Hypothesis}

Based on previous findings (e.g., Fehr \& Gächter, 2000), the author hypothesized that (1) contribution levels would be considerably lower and (2) subjects would assign less punishment points under stranger matching than under partner matching (as used in Denant-Boèmont et al., 2007). 
This assumption is based on the so-called strategies hypothesis introduced by Andreoni (1988). According to this hypothesis, subjects - if they are rational - play in order to influence their partners' actions. As strangers play actually a repeated single shot game, there is no reason for them to play strategically and we can thus expect that they would contribute less than partners. The same reasoning may be used in relation to punishments: the single shot equilibrium presumes zero punishment (see e.g., Fehr \& Gächter, 2000) and there is no reason to expect another result in repeated one-shot interactions where in addition subjects' experience plays a role.

The results of the original experiment showed that a possibility to avenge sanctions considerably decreased individuals' willingness to cooperate while possibility to enforce sanctions had positive effect on the level of contribution. As the Czech strangers' experiment provided the subjects with identical range of punishment strategies available, the author assumed that there was no reason to expect different results relative to impacts of counter punishment and sanction enforcement opportunities.

\section{Results}

\subsection{Average Contributions}

Average individual contributions in four strangers' experimental treatments are shown by Table 2. The highest average contributions were achieved in the No Revenge treatment (13.05 tokens), followed by Baseline (10.46) and Full Information (8.15), and the lowest average contributions were reached in the Revenge Only treatment (5.52). This order copies the results of Denant-Boèmont et al. (2007). However, contribution levels in our experiment were actually considerably lower than in original experiment (where average contributions were 16.17 under the No Revenge treatment, 15.49 under Baseline, 10.59 under Full Information and 7.21 under the Revenge Only treatment). The difference in contribution levels between the two experiments (or the two matching types) varied from 1.69 to 5.03 tokens which supports the first part of the author's hypothesis arguing that subjects contribute considerably less under stranger matching.

Table 2. Average contributions - partners vs. strangers

\begin{tabular}{lcccc}
\hline & \multicolumn{3}{c}{ Treatment } \\
\cline { 2 - 5 } & Baseline & Full Information & No Revenge & Revenge Only \\
\hline Partners - original experiment & 15.49 & 10.59 & 16.17 & 7.21 \\
Std. Deviation & $(3.50)$ & $(4.74)$ & $(4.17)$ & $(3.75)$ \\
Strangers - Czech experiment & 10.46 & 8.15 & 13.05 & 5.52 \\
Std. Deviation & $(7.08)$ & $(6.13)$ & $(6.04)$ & $(5.30)$ \\
\hline
\end{tabular}

Source: Author

Another significant difference in relation to the original experiment was that in the Czech experiment the average contributions had decreasing trend in all four treatments. (In Denant-Boèmont et al. [2007] experiment, the average contribution level didn't noticeably change in any treatment during the game. An exception was decline over time in Revenge Only and an initial increase in the first periods of Baseline and No Revenge.) This finding demonstrated that cooperation was not sustainable solution under stranger matching. Despite high initial contribution levels (mainly in No Revenge treatment), average contributions in all treatments tended over time to zero, which is in line with game theoretic predictions. This trend may be noticed in Figure 1.

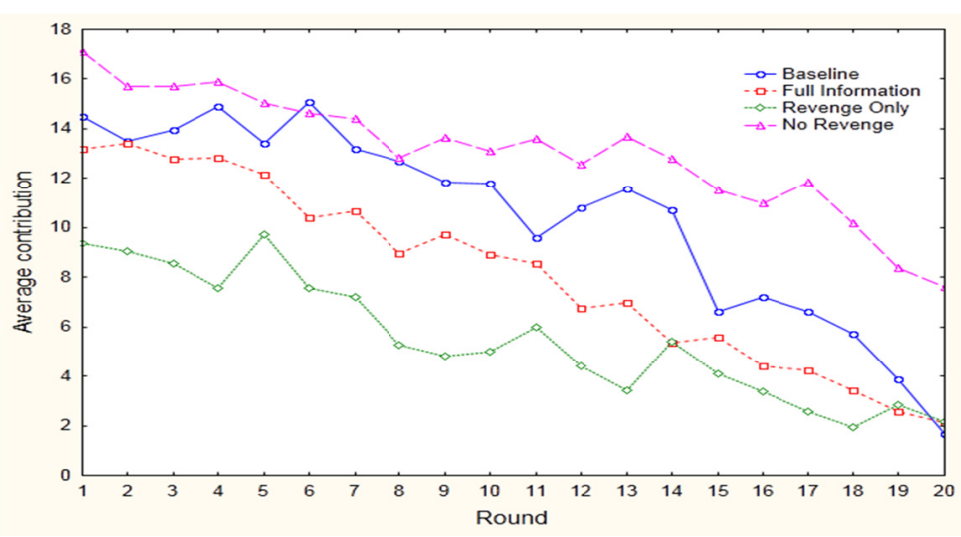

Figure 1. Strangers' average individual contributions (Source: Author) 
In order to evaluate the effects of counter-punishment and sanction enforcement on contributions, the author compared individual contributions between treatments using Chi-squared test (Note 2). The test with the null hypothesis saying that individual contributions of subjects in (two) different treatments represent random draws from identical probability distribution, has a chi-squared distribution with one degree of freedom. A rejection of the hypothesis would indicate that contribution behaviors under compared treatments are significantly different. The test allowed for comparison of all individual contributions over 20 rounds, that is, 480 draws for each treatment.

Like the original experiment, the Czech results reveal that the introduction of an opportunity to counter-punish has a negative effect upon the level of cooperation. The differences in contributions between the Baseline and Revenge Only treatments, as well as between the Full Information and No Revenge treatments, are statistically significant $\left(\chi^{2}\right.$ statistics are significant beyond the 0.001 level). This finding confirms the conclusions of Nikiforakis (2008) and Denant-Boèmont et al (2007) stating that the threat of counter-punishment decreases considerably the level of contributions to a group account. The possibility to enforce sanctions has, by contrast, a positive effect on the cooperation level. The differences in contributions between the Full Information and Revenge Only treatments, as well as between Baseline and No Revenge, are statistically significant (both $\chi^{2}$ statistics significant beyond the 0.001 level). There exists a demonstrable and positive effect of the possibility of sanction enforcement to the level of contribution; however, it is weaker than the negative effect related to the threat of a counter punishment. The difference in the level of contributions between the Baseline and Full Information is statistically significant $\left(\chi^{2}\right.$ significant beyond the 0.001 level) which means that, overall, the effect of counter-punishment and sanction enforcement is negative, that is, the positive effect of the sanction enforcement is not strong enough to counterbalance the negative effect of the counter punishment. This finding strengthens the conclusions of the original experiment.

\subsection{Quantity of Sanctions}

The second part of the hypothesis was related to intensity of sanctions. Average quantity of sanctions assigned under the two matching types may be observed in Table 3 .

Table 3. Average quantity of sanctions

\begin{tabular}{llllll}
\hline & & \multicolumn{3}{c}{ Treatment } \\
\cline { 3 - 6 } & & Baseline & Full Information & No Revenge & Revenge Only \\
\hline \multirow{2}{*}{ Average points assigned in } & Stage 2 & 1.512 & 0.46 & 0.65 & 0.73 \\
Denant-Boèmont et al. (2007) & Stage 3 & - & 0.57 & 0.37 & 0.38 \\
& Both stages & $\mathbf{1 . 5 1 2}$ & $\mathbf{1 . 0 3}$ & $\mathbf{1 . 0 2}$ & $\mathbf{1 . 1 1}$ \\
Average points assigned in the & Stage 2 & 0.68 & 0.15 & 0.52 & 0.30 \\
Czech experiment & Stage 3 & - & 0.24 & 0.18 & 0.31 \\
& Both stages & $\mathbf{0 . 6 8}$ & $\mathbf{0 . 3 9}$ & $\mathbf{0 . 7 0}$ & $\mathbf{0 . 6 1}$ \\
\hline
\end{tabular}

Source: Author

As it is clearly visible from Table 3 , subjects sanctioned considerably more heavily in original experiment, that is, under fixed matching. In the Baseline and Full Information treatments average punishment points overall were even more than double compared to our results. This supports again the author's hypothesis arguing that subjects punish less under stranger matching (that is, when composition of groups changes in each round).

\subsection{Motivation and Effects of Sanctions}

For the studying of motivations and of the incentives for sanction behavior, Denant-Boèmont et al. (2007) have introduced two regression functions, which are explained below. Equation 4 records sanction behavior at the second stage (that is, first punishment stage): The number of punishment points distributed by a subject at the second stage is expressed as an elemental function of others' contributions and of a deviation in the contribution level of a sanctioned subject from the group average.

$$
p_{i}^{j 2 t}=\beta_{0}+\beta_{1} c_{-i}^{-t}+\beta_{2} \max \left\{0, c_{-j}^{-t}-c_{j}^{t}\right\}+\beta_{3} \max \left\{0, c_{j}^{t}-c_{-j}^{-t}\right\}+\beta_{4} t
$$

Variables employed in the equation 5 are indicated as follows: the dependent variable $p_{i}^{j 2 t}$ represents the quantity of points assigned by player $i$ to player $j$ in the second stage of period $t . c_{j}^{t}$ is the contribution of player $j$ in period $t$ while $c_{-j}^{-t}\left(c_{-i}^{-t}\right)$ signifies the average contribution of players in given group other than $j(i)$. The regressions are made separately for all of the 20 periods of a game and the first period (Note 3 ). 
Table 4. Motivations for second stage punishment

\begin{tabular}{|c|c|c|c|c|c|c|}
\hline & \multicolumn{3}{|l|}{ All periods } & \multicolumn{3}{|l|}{ First period } \\
\hline & $\begin{array}{l}\text { Full } \\
\text { information }\end{array}$ & $\begin{array}{l}\text { Revenge } \\
\text { only }\end{array}$ & $\begin{array}{l}\text { No } \\
\text { revenge }\end{array}$ & $\begin{array}{l}\text { Full } \\
\text { information }\end{array}$ & $\begin{array}{l}\text { Revenge } \\
\text { only }\end{array}$ & $\begin{array}{l}\text { No } \\
\text { revenge }\end{array}$ \\
\hline Constant $\left(\beta_{0}\right)$ & $\begin{array}{l}0.061 \\
(0.042)\end{array}$ & $\begin{array}{l}0.242 * * * \\
(0.046)\end{array}$ & $\begin{array}{l}0.300 * * * \\
(0.085)\end{array}$ & $\begin{array}{l}-0.160 \\
(0.368)\end{array}$ & $\begin{array}{l}-0.026 \\
(0.281)\end{array}$ & $\begin{array}{l}0.148 \\
(0.602)\end{array}$ \\
\hline $\begin{array}{l}\text { Others' average } \\
\text { contribution }\left(\beta_{l}\right)\end{array}$ & $\begin{array}{l}-0.005^{*} \\
(0.003)\end{array}$ & $\begin{array}{l}-0.019 * * * \\
(0.004)\end{array}$ & $\begin{array}{l}-0.012 * * * \\
(0.004)\end{array}$ & $\begin{array}{l}-0.005 \\
(0.023)\end{array}$ & $\begin{array}{l}-0.008 \\
(0.025)\end{array}$ & $\begin{array}{l}-0.007 \\
(0.033)\end{array}$ \\
\hline $\begin{array}{l}\text { Amount recipient } \\
\text { contributed below average } \\
\left(\beta_{2}\right)\end{array}$ & $\begin{array}{l}0.033 * * * \\
(0.002)\end{array}$ & $\begin{array}{l}0.048 * * * \\
(0.004)\end{array}$ & $\begin{array}{l}0.063 * * * \\
(0.004)\end{array}$ & $\begin{array}{l}0.104 * * * \\
(0.023)\end{array}$ & $\begin{array}{l}0.128 * * * \\
(0.030)\end{array}$ & $\begin{array}{l}0.064 * * * \\
(0.019)\end{array}$ \\
\hline $\begin{array}{l}\text { Amount recipient } \\
\text { contributed above average } \\
\left(\beta_{3}\right)\end{array}$ & $\begin{array}{l}0.006^{* * *} \\
(0.002)\end{array}$ & $\begin{array}{l}0.009 * * * \\
(0.003)\end{array}$ & $\begin{array}{l}-0.002 \\
(0.004)\end{array}$ & $\begin{array}{l}0.027 \\
(0.020)\end{array}$ & $\begin{array}{l}0.039^{*} \\
(0.022)\end{array}$ & $\begin{array}{l}0.009 \\
(0.031)\end{array}$ \\
\hline Period $\left(\beta_{4}\right)$ & $\begin{array}{l}-0.006 * * * \\
(0.002)\end{array}$ & $\begin{array}{l}-0.015^{* * *} \\
(0.002)\end{array}$ & $\begin{array}{l}-0.012 * * * \\
(0.003)\end{array}$ & & & \\
\hline
\end{tabular}

$* * * 1 \%$ significance level, $* * 5 \%$ significance level, $* 10 \%$ significance level

Source: Author

The Czech results concerning the first regression (see table 4) are mostly in line with those of the original experiment. Negative coefficient on $\beta_{1}$ (significant in Revenge Only and No Revenge treatments and bordering on the significance within the Full Information treatment) indicates that the higher others' average contribution is, the less subject $i$ sanctions her co-players. The coefficient is not that significant in the reception of data only for first period of a game (that is, $t=1$ ) in any period. The positive coefficient on $\beta_{2}$ (significant in all three treatments for both the data for all periods and for separate period one) means that the less $j$ contributed to the group account relative to other players in the group, the more she gets punished by $i$. However, the results show that at the same time, the more $j$ contributes to the group account relative to other co-players, the more he gets punished, as indicated by a positive coefficient on $\beta_{3}$ (significant within Full Information and Revenge Only treatments for data for all periods). This finding is in contradiction with the results of original experiment where $\beta_{3}$ was positive (which seems logical). In case of our subjects, it holds that the more one deviates from the average of a group (no matter in which sense) the more he gets punished.

Equation 5 refers to the motivations of sanction behavior at the third stage (that is, second stage of punishment). In addition to the punishment of low contributors (as it was encapsulated by equation 4), it records the possibility of sanction enforcement and counter-punishment.

$$
\begin{aligned}
p_{i}^{j 3 t}= & \beta_{0}+\beta_{1} p_{j}^{i 2 t}+\beta_{2}\left\{\left(\sum_{m \neq j} \sum_{k \neq i, j} p_{m}^{k 2 t}\right) / 2\right\}+\beta_{3} c_{-i}^{-t}+\beta_{4} \max \left\{0, \sum_{k \neq i} p_{j}^{k, 2 t}-\left(\left(\sum_{m \neq j} \sum_{k \neq i, j} p_{m}^{k 2 t}\right) / 2\right)\right\}+ \\
& \beta_{5} \max \left\{0,\left(\sum_{m \neq j} \sum_{k \neq i, j} p_{m}^{k 2 t}\right) / 2-\sum_{k \neq i} p_{j}^{k, 2 t}\right\}+\beta_{6} \max \left\{0, c_{-j}^{-t}-c_{j}^{t}\right\}+\beta_{7} \max \left\{0, c_{j}^{t}-c_{-j}^{-t}\right\}+\beta_{8} t(5)
\end{aligned}
$$

$p_{i}^{j 3 t}$ represents the punishment points assigned by subject $i$ to $j$ at the third stage of period $t . p_{j}^{i 2 t}$ are punishment points assigned at the second stage by player $j$ to player $i,\left(\sum_{m \neq j} \sum_{k \neq i, j} p_{m}^{k 2 t}\right) / 2$ is average number of punishment points assigned to players other than $i$ and $j$ at the second stage, $\sum_{k \neq i} p_{j}^{k, 2 t}$ is total number of punishment points assigned by $j$ to other individuals than $i$. The variables comprising the average punishment of third parties and $j$ 's deviation from this average are not included in the analysis for Revenge Only treatment, because the individuals don't have the information at disposal. 
Table 5. Motivations for third stage punishment

\begin{tabular}{|c|c|c|c|c|c|c|}
\hline & \multicolumn{3}{|l|}{ All periods } & \multicolumn{3}{|l|}{ First period } \\
\hline & $\begin{array}{l}\text { Full } \\
\text { information }\end{array}$ & $\begin{array}{l}\text { Revenge } \\
\text { only }\end{array}$ & No revenge & $\begin{array}{l}\text { Full } \\
\text { information }\end{array}$ & $\begin{array}{l}\text { Revenge } \\
\text { only }\end{array}$ & No revenge \\
\hline \multirow[t]{2}{*}{ Constant $\left(\beta_{0}\right)$} & $0.187 * * *$ & $0.141 * * *$ & $0.230 * * *$ & 0.211 & -0.127 & $0.917^{*}$ \\
\hline & $(0.056)$ & $(0.047)$ & $(0.063)$ & $(0.238)$ & $(0.136)$ & $(0.535)$ \\
\hline \multirow[t]{2}{*}{$\begin{array}{l}\text { Points j assigned to } \\
\mathrm{i} \text { at } 2 \text { nd stage }\left(\beta_{I}\right)\end{array}$} & -0.008 & $0.052 * * *$ & -0.007 & -0.023 & 0.004 & 0.046 \\
\hline & $(0.020)$ & $(0.019)$ & $(0.014)$ & $(0.055)$ & $(0.050)$ & $(0.085)$ \\
\hline \multirow{2}{*}{$\begin{array}{l}\text { Others' average } \\
\text { punishment at } 2 \text { nd } \\
\text { stage }\left(\beta_{2}\right)\end{array}$} & -0.031 & & $-0.041 * *$ & -0.069 & & -0.128 \\
\hline & $(0.034)$ & & $(0.017)$ & $(0.086)$ & & $(0.098)$ \\
\hline \multirow[t]{2}{*}{$\begin{array}{l}\text { Others' average } \\
\text { contribution }\left(\beta_{3}\right)\end{array}$} & $-0.010 * * *$ & -0.006 & $-0.012 * * *$ & -0.010 & $0.023^{*}$ & $-0.051^{*}$ \\
\hline & $(0.003)$ & $(0.004)$ & $(0.003)$ & $(0.014)$ & $(0.012)$ & $(0.029)$ \\
\hline \multirow{2}{*}{$\begin{array}{l}\text { Positive deviation } \\
\text { of recipient from } \\
\text { average } \\
\text { punishment at } 2 \text { nd } \\
\text { stage }\left(\beta_{4}\right)\end{array}$} & 0.004 & & 0.032 & 0.031 & & 0.433 \\
\hline & $(0.072)$ & & $(0.039)$ & $(0.155)$ & & $(0.394)$ \\
\hline \multirow{2}{*}{$\begin{array}{l}\text { Negative deviation } \\
\text { of recipient from } \\
\text { average } \\
\text { punishment at } 2 \text { nd } \\
\text { stage }\left(\beta_{5}\right)\end{array}$} & 0.017 & & $0.054 * *$ & 0.032 & & 0.178 \\
\hline & $(0.038)$ & & $(0.021)$ & $(0.112)$ & & $(0.107)$ \\
\hline \multirow{2}{*}{$\begin{array}{l}\text { Amount recipient } \\
\text { contributed below } \\
\text { the average }\left(\beta_{6}\right)\end{array}$} & $0.033 * * *$ & $0.011 * * *$ & 0.004 & 0.009 & 0.007 & -0.003 \\
\hline & $(0.003)$ & $(0.004)$ & $(0.003)$ & $(0.013)$ & $(0.015)$ & $(0.016)$ \\
\hline \multirow{2}{*}{$\begin{array}{l}\text { Amount recipient } \\
\text { contributed above } \\
\text { the average }\left(\beta_{7}\right)\end{array}$} & 0.003 & -0.005 & 0.004 & -0.004 & -0.005 & 0.018 \\
\hline & $(0.003)$ & $(0.003)$ & $(0.003)$ & $(0.012)$ & $(0.011)$ & $(0.026)$ \\
\hline \multirow[t]{2}{*}{ Period $\left(\beta_{8}\right)$} & $-0.010 * * *$ & & -0.003 & & & \\
\hline & $(0.003)$ & & $(0.002)$ & & & \\
\hline
\end{tabular}

Source: Author

According to Denant-Boèmont et al. (2007), there are several motivations of the third stage punishment: individuals may wait until the third stage to punish low contributors, they may enforce sanctions of the second stage or counter-punish. Table 5 records estimates from the regression. A significantly positive coefficient on $\beta_{1}$ in Revenge Only treatment indicates the existence of counter-punishment; the more subject $j$ punished $i$ at the second stage the more $i$ punishes $j$ at the third stage. This phenomenon isn't present in the case of Full Information and No Revenge treatments where $\beta_{1}$ is negative but not significant. Coefficient $\beta_{3}$ is negative and significant in No Revenge and Full Information treatments which demonstrates the same tendency for third stage punishments as for the second stage sanctions. Positive coefficient on $\beta_{5}$ indicating the existence of 
sanction enforcement is significant only in No Revenge treatment. (This means that the fewer points $j$ assigns relative to the average punishment of third parties at the second stage, the more $i$ sanctions $j$ at the next stage.) Positive coefficient on $\beta_{6}$ (significant in Full Information and Revenge Only treatments) means that low contributors are sanctioned even at the third stage. In accordance with the original experiment, our data reveal that at the second punishment stage sanction enforcement as well as counter-punishment and (delayed) punishment of low contributors occur.

Equations 6 and 7 encapsulate the effects of sanctions on individual contributions (equation 7) and sanction behavior (equation 8).

$$
c_{i}^{t+1}-c_{i}^{t}=\beta_{0}+\beta_{1} \sum_{k} p_{k}^{i 2 t}+\beta_{2} \sum_{k} p_{k}^{i 3 t}+\beta_{3}\left(c_{i}^{t}-c_{-i}^{-t}\right)
$$

Dependent variable $c_{i}^{t+1}-c_{i}^{t}$ represents the difference in contribution levels of individual $i$ between period $t$ and $t+1 . \sum_{k} p_{k}^{i 2 t}$ is the total number of punishment points assigned to player $i$ at the second stage of period $t$, whilst $\sum_{k} p_{k}^{i 3 t}$ is a sum of punishment points assigned to $i$ at the third stage. The last variable represents the deviation of $i$ 's contribution from the others' average contribution.

Table 6. Effect of sanctions on change in contribution

\begin{tabular}{|c|c|c|c|c|c|c|}
\hline & \multicolumn{3}{|c|}{ Low contributors (all periods) } & \multicolumn{3}{|c|}{ High contributors (all periods) } \\
\hline & $\begin{array}{l}\text { Full } \\
\text { information }\end{array}$ & $\begin{array}{l}\text { Revenge } \\
\text { only }\end{array}$ & $\begin{array}{l}\text { No } \\
\text { revenge }\end{array}$ & $\begin{array}{l}\text { Full } \\
\text { information }\end{array}$ & $\begin{array}{l}\text { Revenge } \\
\text { only }\end{array}$ & $\begin{array}{l}\text { No } \\
\text { revenge }\end{array}$ \\
\hline \multirow{2}{*}{ Constant $\left(\beta_{0}\right)$} & 0.000 & 0.145 & $-1.522 * * *$ & -0.223 & $0.939 *$ & $-1.256 * *$ \\
\hline & $(0.000)$ & $(0.410)$ & $(0.505)$ & $(0.530)$ & $(0.518)$ & $(0.519)$ \\
\hline \multirow{2}{*}{$\begin{array}{l}\text { Points received at the } \\
\text { second stage of period } t\left(\beta_{l}\right)\end{array}$} & $0.500 * * *$ & $0.711 * *$ & $0.570^{* *}$ & 1.291 & 0.594 & 0.038 \\
\hline & $(0.000)$ & $(0.284)$ & $(0.264)$ & $(3.066)$ & $(0.832)$ & $(1.393)$ \\
\hline \multirow[t]{2}{*}{$\begin{array}{l}\text { Points received at the third } \\
\text { stage of period } t\left(\beta_{2}\right)\end{array}$} & $2.000 * * *$ & -0.507 & $0.976 * *$ & -0.975 & 0.603 & -2.782 \\
\hline & $(0.000)$ & $(0.363)$ & $(0.474)$ & $(3.307)$ & $(1.001)$ & $(2.257)$ \\
\hline \multirow{2}{*}{$\begin{array}{l}\text { Deviation from others' } \\
\text { average contribution in } \\
\text { period } t\left(\beta_{3}\right)\end{array}$} & $-1.500 * * *$ & -0.137 & $-0.351 * * *$ & $-0.510 * * *$ & $-0.708 * * *$ & $-0.219 * *$ \\
\hline & $(0.000)$ & $(0.095)$ & $(0.090)$ & $(0.087)$ & $(0.080)$ & $(0.091)$ \\
\hline
\end{tabular}

Source: Author

In accordance with Denant-Boèmont's et al. (2007) model, the author conducted a separate analysis for high contributors (those who contribute more than the average in given period) and low contributors (who contribute below group average). The estimates are recorded in Table 6 . Positive coefficient on $\beta_{1}$ for low contributors (significant in all three treatments) indicates that the more punishment points subjects obtain in period $t$ (in which they contributed below the average), the more they raise their contributions in period $t+1$ (in relation to $t$ ). However, this is not the case for high contributors for which $\beta_{1}$ is not significant in any treatment. Coefficient on $\beta_{2}$ is ambiguous in sign and shows no general behavioral pattern for either high or low contributors. Negative coefficient on $\beta_{3}$ (significant for low contributors in the No Revenge and Full Information treatments and for high contributors in all three treatments) indicates the existence of regression to the mean in contributions (independent of the number of sanctions received): this means that "the higher one's contribution relative to the average, the stronger the tendency is to lower it in the following period" (Denant-Boèmont et al., 2007). Reactions observed in contribution behavior on received sanctions were again consistent with those of the original experiment.

The last equation (7) records changes in sanction behavior depending on received punishments.

$$
\sum_{k} p_{i}^{k, 2, t+1}-\sum_{k} p_{i}^{k, 2, t}=\beta_{0}+\beta_{1} \sum_{k} p_{k}^{i 3 t}+\beta_{2}\left(\sum_{k} p_{i}^{k 2 t}-\overline{\sum_{k} p_{J}^{2 t}}\right)
$$

Dependency variable $\sum_{k} p_{i}^{k, 2, t+1}$ represents the difference in total number of punishment points assigned by individual $i$ at the second stage between period $t$ and $t+1$. Expression $\sum_{k} p_{i}^{k 2 t}-\overline{\sum_{k} p_{J}^{2 t}}$ stands for deviation of $i$ 's sum of punishment points assigned from average number of points assigned by group players in second stage of period $t$. (This variable is not known by subjects in Revenge Only and thus is not included in analysis of this 
treatment.) The regressions are conducted separately for low and high punishers (relative to the average number of punishment points distributed in a group in a given period).

Table 7. Effect of received sanctions on punishment in the following period

\begin{tabular}{|c|c|c|c|c|c|c|}
\hline & \multicolumn{3}{|c|}{ Low punishers (all periods) } & \multicolumn{3}{|c|}{ High punishers (all periods) } \\
\hline & $\begin{array}{l}\text { Full } \\
\text { information }\end{array}$ & $\begin{array}{l}\text { Revenge } \\
\text { only }\end{array}$ & $\begin{array}{l}\text { No } \\
\text { revenge }\end{array}$ & $\begin{array}{l}\text { Full } \\
\text { information }\end{array}$ & $\begin{array}{l}\text { Revenge } \\
\text { only }\end{array}$ & $\begin{array}{l}\text { No } \\
\text { revenge }\end{array}$ \\
\hline \multirow[t]{2}{*}{ Constant $\left(\beta_{0}\right)$} & -0.038 & 0.013 & 0.158 & 0.268 & $-1.308 * * *$ & 0.107 \\
\hline & $(0.067)$ & $(0.051)$ & $(0.142)$ & $(0.314)$ & $(0.275)$ & $(0.314)$ \\
\hline \multirow{2}{*}{$\begin{array}{l}\text { Points received at the } 3 \mathrm{rd} \\
\text { stage of period } t\left(\beta_{I}\right)\end{array}$} & $0.074 *$ & $0.242 * * *$ & 0.016 & -0.045 & 0.319 & -0.426 \\
\hline & $(0.042)$ & $(0.085)$ & $(0.111)$ & $(0.266)$ & $(0.236)$ & $(0.642)$ \\
\hline \multirow{2}{*}{$\begin{array}{l}\text { Deviation from average } \\
\text { punishment at the } 2 \text { nd stage } \\
\text { of period } t\left(\beta_{2}\right)\end{array}$} & -0.120 & & -0.229 & $-1.768 * * *$ & & $-1.318 * * *$ \\
\hline & $(0,123)$ & & $(0.156)$ & $(0.341)$ & & $(0.241)$ \\
\hline
\end{tabular}

Source: Author

The data reveal no general pattern concerning the coefficient on $\beta_{1}$. In the case of low punishers, the coefficient is positive but significant only for data obtained under Revenge Only treatment (and bordering significant in Full Information). As in Revenge Only treatment, sanctions assigned at the third stage are interpreted only as counter-punishment, this would mean that the more a subject gets (counter-) punished at the third stage of period $t$, the more he sanctions at the second stage of the following period. This phenomenon is contrary to the main findings of experiments studying the effects of counter-punishment, concluding that the possibility of avenging sanctions leads to lower willingness to engage in sanctioning (e.g., Nikiforakis, 2008). While for low punishers the negative coefficient on $\beta_{2}$ is not significant in any treatment, it is significant in both Full Information and No Revenge treatments for high punishers. This means that the more individuals punish in excess of the average number of punishment points at the third stage of a given period, the less they sanction in next period. This finding is in accordance with the results of the original experiment.

The data acquired under stranger matching confirmed our hypothesis regarding cooperation and willingness to sanction the free riders in different matching types. The Czech subjects contributed and punished less than partners in the original experiment. Another strong difference in relation to the original experiment was that in our experiment the average contributions tended to zero, that is, to the theoretically predicted equilibrium.

When discussing impacts of counter-punishment and sanction enforcement on contribution behavior, motivations and effects of sanctions, the Czech results were mostly in accordance with those of the original experiment. The author observed only two important differences included in the results: 1) The less the subjects contributed relative to the group average, the more they were punished by their co-players. At the same time, however, the more they contributed relative to the group average, the more they got punished. One would say that the players punished every conduct which was not average. 2) The second difference were "curious" reactions in sanction behavior of players in Revenge Only treatment in response to received counter-punishments. One would say that the threat of counter-punishment wasn't strong enough to influence the willingness to engage in second-stage sanctioning (or influenced it in an inverse sense). However, contributions and individual earnings under Revenge Only treatment were the lowest observed among all treatments, which would support the assumption of credibility of counter-punishment threat (in accordance with Nikiforakis, 2008).

\subsection{Control Partners' Group}

In order to eliminate the possibility that the differences were caused partly by country effects, the author executed four control sessions using partner matching. Average contributions attained in four partners' treatments were as 
follows: 17.88 tokens in Full Information treatment, 17.37 in No Revenge treatment, 17.35 in Baseline and 16.66 in Revenge Only treatment (as recapitulated by Table 8). The level of cooperation in all four treatments exceeded that attained in the original partner experiment (see Table 2). We can thus exclude that low cooperation of our strangers' participants would be caused for example by general disinclination of the Czechs to contribute to public goods. On the contrary, it showed up that the Czech partners cooperated considerably more than the French ones and the differences in contributions between our strangers and the subjects of the original experiment weren't caused by what we call country effects.

The results concerning contributions, however, demonstrated one unexpected outcome. The average level of cooperation in all four treatments was very high (about $85 \%$ ) no matter the sanction strategies available. This is in contradiction to the hypotheses and results of the original experiment and the Czech strangers' experiment.

Moreover, the Czech partners only seldom engaged in sanctioning. The average number of sanctions (over both punishment stages) was 0.68 points in Baseline, 0.25 in Full Information, 0.42 in No Revenge and 0.72 in the Revenge Only treatment (as encapsulated by Table 8 ).

Table 8. Average contributions and points assigned in Czech Partners

\begin{tabular}{llllll}
\hline & & \multicolumn{3}{c}{ Treatment } \\
\cline { 3 - 6 } & & Baseline & Full Information & No Revenge & Revenge Only \\
\hline Average contribution & & 17.35 & 17.88 & 17.37 & 16.66 \\
Std. Deviation & & $(0.92)$ & $(0.82)$ & $(1.22)$ & $(1.30)$ \\
& Stage 2 & 0.68 & 0.13 & 0.29 & 0.21 \\
Average points assigned & Stage 3 & - & 0.11 & 0.12 & 0.51 \\
& Both stages & 0.68 & 0.25 & 0.42 & 0.72 \\
\hline
\end{tabular}

Source: Author

While the results of Czech Partners support the part of our hypothesis related to level of cooperation under different matching, they contradict the part concerning willingness to sanction free riders. There are several possible interpretations of this finding. The first could be that the Czechs are generally less willing to punish free riding (it could be a sort of cultural manifestation). However, before drawing such conclusion it is necessary to execute further experiments with the Czech subjects using the punishment opportunity. The other and the more probable interpretation relates to the effectiveness of decentralized punishment as a tool increasing the level of cooperation. If the threat of punishment is strong enough, potential free-riders are discouraged from defecting; they do cooperate and, as a logical consequence, there is no punishment carried out. In other words, the absence of frequent punishment indicates its effectiveness at fostering cooperation (Johnson, 2012; Gintis \& Fehr, 2012).

\section{Discussion}

In line with findings published up to date, the results of the experiment show that people are willing to punish free riders although such act is costly for them. When the threat of punishment is credible enough, people tend to cooperate more. This implies that decentralized punishment represents an important feature for explaining human cooperation. A willingness to punish defectors exists even in case of strangers, that is, subjects who have never met or/and will not meet again. However, according to the results acquired, such subjects engage in altruistic punishment less frequently and the level of their cooperation is weaker. This is in line with author's expectations based on strategies hypothesis.

Moreover, the cooperation is weakened if there is a possibility to avenge sanctions. On the other hand, if subjects have opportunity to enforce their sanctions, the level of cooperation is higher. These two findings correspond to results of the original experiment (Denant-Boèmont et al., 2007).

Some scholars (see e.g., Guala, 2012) criticize the non-existence of studies investigating altruistic punishment in a natural setting. However, as Gächter (2012, p. 26) states: "in equilibrium punishment will be rare and therefore may be hard to observe in the field". Gintis and Fehr (2012) provide an example "from the wild" concerning drivers: while most of them receive several traffic citations during their lives, many drivers adjust their driving in order to prevent citations. The Czech results obtained in partner matching support such conclusion: in majority of groups very few sanctions were imposed and very high levels of cooperation (even full cooperation) were attained over all sessions, no matter the type of treatment. However, as stated above, in case of strangers the threat of 
punishment was not strong enough to discourage the free riders and high level (or full) cooperation was not a sustainable solution.

This paper contributes to the existing literature dealing with cooperation in VCM experiments under partner and stranger matching. It shows that subjects, who interact only once, are less willing to cooperate and more tolerant to free riding. As results up to now have shown, there is no clear pattern between matching types and level of cooperation. Some studies have concluded that partners cooperate more than strangers, while other demonstrated the opposite and some found no differences at all. This question thus remains atopic open to further research.

\section{Acknowledgements}

The author would like to thank her supervisor Jiř́ Špalek for his support and advice. She is also grateful to Fabio Padovano, Yvon Rocaboy and participants of the PEARL seminar 2012 in Helsinki, where the preliminary version of this paper (Berná \& Špalek, 2013) was presented. This research was realized and funded within research projects MUNI/A/0778/2012 and MUNI/M/0045/2013 at Masaryk University.

\section{References}

Andreoni, J. (1988). Why free ride?: Strategies and learning in public goods experiments. Journal of Public Economics, 37(3), 291-304. http://dx.doi.org/10.1016/0047-2727(88)90043-6

Andreoni, J., \& Croson, R. (2008). Partners versus strangers: Random rematching in public goods experiments. In Plott, C. R., \& Smith, V. L. (Eds.), Handbook of experimental economics results, 1 (pp. 776-783). Amsterdam, Netherlands: North-Holland. http://dx.doi.org/10.1016/S1574-0722(07)00082-0

Berná, Z., \& Špalek, J. (2013). The decentralization of punishments in experiments with public goods. Working Paper WPKVE - 05/2013. Retrieved from http://papers.ssrn.com/sol3/papers.cfm?abstract_id=2260962

Bochet, O., Page, T., \& Putterman, L. (2006). Communication and punishment in voluntary contribution experiments. Journal of Economic Behavior \& Organization, 60(1), 11-26. http://dx.doi.org/10.1016/j.jebo.2003.06.006

Casari, M. (2012). Weak reciprocity alone cannot explain peer punishment. Behavioral and Brain Sciences, 35(01), 21-22. http://dx.doi.org/10.1017/S0140525X11001191

Dawes, R. M. (1975). Formal Models of Dilemmas in Social Decision Making. In M. F. Kaplan, \& S. Schwartz, (Eds.), Human Judgment and Decision Processes (pp. 87-107). New York: Academic.

Dawes, R. M. (1980). Social dilemmas. Annual review of psychology, 31(1), 169-193. http://dx.doi.org/10.1146/annurev.ps.31.020180.001125

Denant-Boèmont, L., Masclet, D., \& Noussair, C. N. (2007). Punishment, counterpunishment and sanction enforcement in a social dilemma experiment. Economic theory, 33(1), 145-167. http://dx.doi.org/10.1007/s00199-007-0212-0

Egas, M., \& Riedl, A. (2008). The economics of altruistic punishment and the maintenance of cooperation. Proceedings of the Royal Society B: Biological Sciences, 275(1637), 871-878. http://dx.doi.org/10.1098/rspb.2007.1558

Fehr, E., \& Gächter, S. (2000). Cooperation and punishment in public goods experiments. The American Economic Review, 90(4), 980-994. http://dx.doi.org/10.1257/aer.90.4.980

Fehr, E., \& Gächter, S. (2002). Altruistic punishment in humans. Nature, 415(6868), $137-140$. http://dx.doi.org/10.1038/415137a

Fischbacher, U. (2007). z-Tree: Zurich toolbox for ready-made economic experiments. Experimental economics, 10(2), 171-178. http://dx.doi.org/10.1007/s10683-006-9159-4

Gintis, H., \& Fehr, E. (2012). The social structure of cooperation and punishment. Behavioral and Brain Sciences, 35(1), 28-29. http://dx.doi.org/10.1017/S0140525X11000914

Guala, F. (2012). Reciprocity: Weak or strong? What punishment experiments do (and do not) demonstrate. Behavioral and Brain Sciences, 35(1), 1-59. http://dx.doi.org/10.1017/S0140525X11000069

Herrmann, B., Thöni, C., \& Gächter, S. (2008). Antisocial punishment across societies. Science, 319(5868), 1362-1367. http://dx.doi.org/10.1126/science.1153808

Johnson, T. (2012). The strategic logic of costly punishment necessitates natural field experiments, and at least one such experiment exists. Behavioral and Brain Sciences, 35(01), 31-32. http://dx.doi.org/10.1017/S0140525X11000926 
Nemec, J. (1998). Úloha štátu v tranzitívnej ekonomike: vybrané mikroekonomické aspekty. Ekonomický časopis, 46(05), 655-670.

Nikiforakis, N. (2008). Punishment and counter-punishment in public good games: Can we really govern ourselves?. Journal of Public Economics, 92(1), 91-112. http://dx.doi.org/10.1016/j.jpubeco.2007.04.008

Nikiforakis, N., \& Engelmann, D. (2011). Altruistic punishment and the threat of feuds. Journal of Economic Behavior \& Organization, 78(3), 319-332. http://dx.doi.org/10.1016/j.jebo.2011.01.017

Nikiforakis, N., \& Normann, H. T. (2008). A comparative statics analysis of punishment in public-good experiments. Experimental Economics, 11(4), 358-369. http://dx.doi.org/10.1007/s10683-007-9171-3

Ostrom, E., Walker, J., \& Gardner, R. (1992). Covenants with and without a sword: Self-governance is possible. The American Political Science Review, 86, 404-417. http://dx.doi.org/10.2307/1964229

Šeneklová, J., \& Špalek, J. (2009). Jsou ekonomové jiní? Ekonomický model versus realita. Politická ekonomie, 1, 21-45.

Špalek, J., \& Berná, Z. (2011). Threshold Effectiveness in Contributing to the Public Goods: Experiments Involving Czech Students. Prague Economic Papers, 3, 250-267.

Špalek, J., \& Berná, Z. (2012). Effectiveness of Charitable Lottery Design: Experimental Evidence from the Czech Republic and Russia. Ekonomický časopis, 60(3), 239-258.

\section{Notes}

Note 1 . The second issue the authors examined was the effect of multiple opportunities to sanction. This question was not topic of the author's replication.

Note 2. The design of the test is described in Andreoni (1988).

Note 3. For more technical details on regression functions, see Denant-Boèmont et al. (2007). In this paper, only the results of the analysis are presented without explaining in detail the derivation of regression equations.

\section{Copyrights}

Copyright for this article is retained by the author(s), with first publication rights granted to the journal.

This is an open-access article distributed under the terms and conditions of the Creative Commons Attribution license (http://creativecommons.org/licenses/by/3.0/). 